\title{
Bond to Bondage: Stolen Generation Musings in Sally Morgan's My Place
}

\author{
Dr. S. J. Kala and R. Sri Vidhya
}

\begin{abstract}
Australian Aboriginal literature is a new arena in Australia's literary scenario. Aboriginal women's writing has gained special credit in the recent years for its varied themes and concerns related to the indigenous studies. One such writer is Sally Morgan, a mixed-blood Australian whose works have gained immense credit in Australia's literary world. Her maiden creation, My Place is both an autobiography and a testimonial writing on the Stolen Generation of Australia. The objective of this article is to identify the aborigines, and to trace the veiled history of the Australian Stolen Generation. It will also explore the bleak past of the afflicted inmates at the foster homes with reference to Daisy, Arthur and Gladys featuring in My Place. In the due course of the study the buried past of the Stolen Generation will not just be unearthed but the murky lives of the contemporary Australian aborigines will also be shed light on.
\end{abstract}

Keywords-Australian, Aboriginal, Stolen Generation, mixed-race.

Aboriginal writing in Australia began as a revolutionary attempt in rewriting the history of the land and its people against the fictionalised white-washed history that came from the whites. There are also many mixed-blood Aboriginal women writers in the literary scenario whose personal writings as mixed-race, gain much more attention from readers who wish to learn the history and lives of the Stolen Generation in Aboriginal Australia. Lucie Wanderburgova says, "what is also quite interesting is the fact that most of the narrators of the Stolen Generation issue have been women and that the best known testimonies regarding removals has been autobiographical works" (Wanderburgova 11). Some of the notable Aboriginal women writings are Margaret Tucker's If Everyone Cared (1977), Monica Clare's Karobran: The Story of An Aboriginal Girl (1978), Ella Simon's Through My Eyes (1978) and Ida West's Pride Against Prejudice (1987).

The role of mixed-race descendant writers in transcribing the lives of their ancestors - the affected members of the Stolen Generation, through biographies, testimonies and life-writings is exemplary. Such mixedrace descendants, though not belonging to the Stolen Generation are equally affected as the Stolen Generation members for they are deprived of their ancestral roots due to survival strategies that resulted in identity crisis.

One such writer is Sally Morgan, who though not a Stolen Generation member, for the fact that she is a mixed-race descendant, feels that it is her duty to give voice for the concerns of both the full-blood and the mixed-blood aborigines through her writings. Her auto/biographical work, My Place is considered to be perhaps the best known work by an aboriginal writer.
Lucie Wanderburgova in her thesis quoting Newman says that the work "will long be regarded as a landmark text in Australian writing" (Wanderburgova 20). Chronicling Jack Healy's view Carolyn Bliss affirms that My Place as "the finest example... to date" of "the reconnecting of the broken tissue of Aboriginal identity..." (Bliss 65). The book received many awards including "the 1987 Human Rights and Equal Opportunities Commission Award for Literature, the 1988 Braille Book of the Year award and the 1989 Western Australian Citizen of the Braille Book of the Year award and the 1989 Western Australian Citizen of the year Award for arts, literature and culture" (Sonoda 158).

Lucie Wanderburgova underscores the educative power of the work: "My Place became part of an Aboriginal Studies programme and belongs to the compulsory literature for Australian students in public schools" (Wanderburgova 16). She uses the quotation of Schaffer and Smith and says that My Place was "the first to be actively celebrated, heavily marketed, and critically promoted" (Wanderburgova 61).

Sally Morgan's My Place is a representative work in various aspects. It is both an autobiography and a testimonial writing. The writer through her autobiography represents her community of mixed-race descendants who do not belong to the Stolen Generation, while at the same time represent the affected members of the Stolen Generation, through her testimonies. We not only "learn to sympathize and identify with the young girl" as Morgan, but also with each person's testimony (Hills 106). It cannot also be denied that her writing is both auto/biography, for she "incorporates the collaborative lifewriting projects of Arthur, Gladys and Daisy" (Smith 532) and it shows 
"Morgan's anxiety to make as many Aboriginal voices audible as possible" (Rani 93). The work incorporates various literary genres like autobiography, testimony, and the Stolen Generation narrative. On the whole the work stands to be a representation of the lives of the mixed-race descendants irrespective of whether or not they belong to the Stolen Generation.

What is more important in dealing with the issue of the Stolen Generation is that the facts should be given without fiction. Authenticity is vital in dealing with such a burning political and social issue. Sally Morgan's auto/biography carries real life characters sharing real life experiences and therefore represents the whole community of neglected Aborigines and the mixed-race people. Highlighting Lucie Wanderburgova's opinions, “...true life-stories are always highly effective' and '... the fact that the protagonists are/were real people makes the reading even more exciting and poignant" and to add to it, it is even more authentic (Wanderburgova 67,68).

Sally Morgan is currently a professor of Indigenous Studies and the director of the Centre for Indigenous History and the Arts at the School of Indigenous Studies, the University of Western Australia. According to Suneeta Rani writers like Sally Morgan, "were urbanised, educated, self-reliant and actively involved in the Aboriginal movement, with a background of removal from the Aboriginal societies,..." (Rani 52).

The novel My Place carries the life-writings of three generations of mixed-blood aborigines in Sally Morgan's family that includes Sally Morgan's life as a mixed-blood free Australian, her mother Gladys, a Stolen Generation member and Sally Morgan's grandmother Daisy and her brother Arthur who were again members of the Stolen Generation. The testimonies of Gladys, Daisy and Arthur show the true picture of the lives of Stolen Generation members in foster homes and their consciousness as aborigines.

The objective of this article is to identify the aborigines, and to trace the veiled history of the Australian Stolen Generation. It will also explore the bleak past of the afflicted inmates at the foster homes with reference to Daisy, Arthur and Gladys featuring in My Place. In the due course of the study the buried past of the Stolen Generation will not just be unearthed but on the murky lives of the contemporary Australian aborigines will also be shed light on.

The term Aboriginal (Latin: 'Ab' - 'from' and 'Origin' - 'beginning') is used to define the indigenous people of Australia as early as 1789. Aborigines are the primitive inhabitants of Australia who came to the land at least 30,000 years ago. The historical evidence of
Aboriginal people shows that they are one of the oldest continual civilizations in the world.

The British colonial invasion in the aboriginal land of Australia happened in the year 1788. They called themselves as 'protectors' of the native community and the civilizing masters of the ignorant mob. The white colonizers used various strategies to wipe out the native race and they almost succeeded in their attempts when the aborigine population began to decline and its ratio touched an all time low.

However, the entire native race could not be wiped out as there began mushrooming of mixed-blood children with aboriginality in their blood. This new race of mixed-blood population posed a threat to the colonial masters as they could not be led to live with their aboriginal community which would result in the increase of the aboriginal population; nor could they be allowed to live in the whites community as those mixed-race children had a little of black blood in them. Hence they were removed from their aboriginal communities who came to be branded as the 'Stolen Generation' of Australia. According to Lucie Wanderburgova the term 'Stolen Generation' was first used by Peter Read as title for a magazine article which was then followed by a book The Stolen Generations (1981) (Wanderburgova 31).

Children and babies were removed from their families either by force or trickery to be placed in 'girls' and 'boys' homes, foster families or missions. They were totally cut off from any kind of contact with their Aboriginal families and were severely punished if they did try to run off to their community from white control. Instead of education, they were trained to be domestic workers. At the age of 18 they were 'released' into the white society, often scared for survival in white society due to the hostile experiences in such foster homes and missions. Such forced removal of mixed-blood children from their aboriginal families fills the dark pages of the history of Australia.

In the novel My Place, the testimonies of Gladys, Daisy and Arthur clearly show that only children of mixed descent were removed by the authorities from the Aboriginal clan, on account of the 'white blood' in them. Blacks were not "considered fit to raise a child with white blood" to put it in Nan's words (Morgan 415). She also expresses her vehemence saying, "they didn't like people like us rearin' kids with white blood in them. Seems like no one took account of the black blood" (Morgan 428). For the same reason, full-blood Aboriginal children were not removed. The worst condition of being an Aboriginal was therefore more prominent in the mixed-blood children, as members of the Stolen Generation. 
Such mixed-blood children were either removed by force or through strategic means. In My Place, we learn that Daisy, Arthur and Gladys were all removed by strategic means - under the pretext of giving education. Arthur shares how he was removed from his family, "they told my mother and the others we'd be back soon. We wouldn't be gone for long, they said" (Morgan 231). The Aboriginal people ignorantly hoped that their children would be back some day. The ignorance and the helplessness of the Aboriginal people were also cleverly misused for removal.

The same helplessness was felt when the children were removed by force - "the most heart-rending image is the one conveyed of small black children crying and begging to be allowed to stay with their mothers, but being harshly pulled away as they clung to their mothers" (Pruthi 68). One person in the "Bringing Them Home" report says, "the biggest hurt, I think, was having my mum chase the welfare car - I'll always remember it - we were looking out the window and mum was running behind us and singing out for us" (Bringing 40). The same helpless situation occurs in Doris Pilkington's Follow the RabbitProof Fence also when the three young girls were forcefully removed from their home.

The threat to and uncertainty of life was also experienced by the Aboriginal community, when children were suddenly abducted illegally without proper intimation. It is indeed right that they were termed the 'Stolen Generation', for in many cases children were literally stolen from the community without notice. Bringing Them Home report carries instances of many such shocking and sudden removals that traumatised both the mothers and the children.

There are also cases of parents who themselves willingly accepted the removal of their children for various reasons. Their incapability to feed and raise the children due to poverty, and their desire for the children to grow up in better living condition, free from diseases and malnutrition, let them willingly accept the removal, as evidenced from the report. "We have spoken with people who, even today, honestly believe that it was right to transfer indigenous children into white families because this would give them the material benefits they would not otherwise have" (Bringing 230).

The mixed race children were removed and segregated further. The racist consciousness was so powerful in the whites that they separated children according to the proportion of colour in them "Aborigines were categorized by how much Aboriginal blood they had (full-blood, half-caste, quadroon), or how visibly Aboriginal they looked" (Kennedy 13). Arthur tells his experience of how an English authority visited the mission and separated the 'darker kids' from the 'lighter kids', for "he didn't like (them) being together" (Morgan 233). Such constant separations deprived children of having any intimacy or companionship among themselves.

Under the disguise of 'protectors' for the Aborigines the white authorities exercised a stranglehold of power in their lives that resulted in the distrust. Lucie Wanderburgova, in her thesis, says, "The officials were labeled as 'protectors' and their task was to control the lives and the geographical location of Aboriginal people of mixed parentage" (Wanderburgova 32). The historical figure, A O Neville, the Chief Protector of Natives, Western Australia, 1915-1940, himself failed to 'protect' the Aborigines and turned against them by activating legal policies like 'miscegenation' and the removal of 'halfcaste' Aboriginal children from their mothers. Arthur too says that Neville "was still the Protector of Aborigines. Any blackfella that had dealings with Neville got no good word to say about him. He wasn't protectin' the Aborigines, he was destroyin' them" (Morgan 265). The fear for authority and removal are constant throughout their lives.

Due to removal from aboriginal mothers and due to the fact that the white masters did not want to own their half-caste offsprings, these mixed-blood Stolen Generation children grew up without the knowledge of who parented them. The difficulty of Gladys in knowing her white father, the mere 'blank' against the name of the father in her birth certificate, makes the view evident. Also Sally says, "Hardly any Aboriginal people had birth certificates those days" (Morgan 193). Daisy faces the same split identity - "As Daisy Brockman, she is the daughter of the station owner; as Daisy Corunna, she is the 'daughter of the station', that is, the daughter of no-one in particular" and "her white father's denial places her in the position of an illegitimate half-caste child" (Kennedy 4,5).

Identity crisis faced by the mixed-blood children does not end here. They face split-identity in their foster homes where they had their Aboriginal names changed, their basic source of Aboriginal identity and then were deprived of using Aboriginal language, by the replacement of the colonizer's language, English. They were also forced to change their Aboriginal religion to Christianity. Thus the change of name, language and religion resulted in the loss of one's basic identity. Arthur informs, "the first thing they did was christen us" (Morgan 232). In fact the very opening lines of Daisy's testimony reflect a sense of loss of identity, "My name is Daisy Corunna, I'm Arthur's sister. My Aboriginal name is Talahue" (Morgan 402). She also adds that in those days, "All the natives had 
whitefella and tribal names" (Morgan 402). In many cases, they were not even given names, but numbers, as if they were prisoners - "for 18 years the state of Victoria referred to me as State Ward No 54321" (Bringing 58). The children were thus made the wards of the state and inherited as government properties.

Once when name which is the basic identity of a person is removed, the next step was the removal of one's mother tongue. The children in foster homes were not allowed to use their Aboriginal language and restricted from speaking it. Arthur in My Place undergoes a similar experience, while he was deprived of using his language and forced to talk English. He recalls saying, "I wasn't allowed to talk blackfella after that" and adds, "I liked my language, but I got a good hiding if I spoke it. I had to talk English" (Morgan 227). Children were also taught that it was a shame to use Aboriginal language. Veronica Brady in her article observes: "There was a deliberate attempt to make them feel ashamed of their own culture and to destroy their language" (Brady 3). Daisy feels ashamed to use her language in front of people and secretly uses it while communicating with Arthur. Aboriginal people today mostly speak English, with a few Aboriginal phrases and words that contribute to Australian Aboriginal English making the original Aboriginal language extinct.

The tribal religion was also replaced by Christianity and the children were made to follow the new religion forced on them. "Then the religion began. We had church three times a day, before breakfast, lunchtime and after school", Millicent, a Stolen Generation member reports (Bringing 100). Gradually the children were distanced from their Aboriginal spiritual traditions and they assimilated and started to believe in the new religion through constant practice as it is with the case of Gladys "I became what others refer to as a believer" (Morgan 126). In fact, the presence of two distinct spiritual traditions - Christianity and Aboriginal spirituality is found in all the characters in My Place.

These changes were done with the aim that "Culture, language, land and identity were to be stripped from the children, so that "the traditional law and culture would die by losing their claim on them and sustenance of them" (Bringing 175). Resultantly, children grew up without any cultural and traditional knowledge and were totally devoid of their heritage and hence ended up with the loss of identity and Aboriginal consciousness.

The loss of a mother's love, care, warmth and comfort affected the children much more than the other factors. Separated so young, they grew up with longing for the comfort of their mother and more acute were the yearnings of the children who were removed as infants as they had no experience of such motherly care. Gladys recalls how she was deprived of having her mother's comfort when she was ill, "even when I was sick, I belonged to the Native Welfare department. I wasn't even allowed to have the comfort of my own mother" (Morgan 315). For the little children, the sufferings were even harder and indescribable. Gladys expresses her sympathy for the little children saying, "I felt sorry for them, they all wanted mothers, too" (Morgan 337).

Togetherness of the little ones in the foster homes, was the only comforting factor that they had. Veronica Brady sums up the kind of good times, that the segregated mixed-blood kids had in the homes: "we also hear about good times, of fun the children had together, swimming in the river or hunting and looking for food in the bush, visiting the old people down at the camp, and so on" (Brady 3). Gladys' testimony that takes us back to her days in Parkerville reflects similar rare cheerful moments. However, it cannot be denied that there always prevailed a sad reality behind every cheerful laugh. Veronica Brady herself admits that these children are always "objects of pity, not the strong, courageous, adaptable and life loving people that they are" (Brady 3).

Whites also portray blacks as 'bad influence' and that blacks were "dirty, untrustworthy, (and) bad" to both Aboriginal and non-Aboriginal children (Read 12). Sue Thomas quotes from Frantz Fanon's The Wretched of the Earth, saying "Racist discourses present Aboriginality as the absence of negation of white ethnocentric values 'intelligence, rationality, productivity, discipline and cleanliness" (Thomas 1,2). Gladys expresses the same: "The Home taught us never to talk openly about being Aboriginal. It was something we were made to feel ashamed of" (Morgan 330).

This kind of attitude is instilled in the minds of young children of both races and to the mixed-blood children who were not stolen also. Sally and her siblings face constant abasement in schools where they were thought 'a contaminating influence' on the white children. Sally admits saying, "there was a great deal of social stigma attached to being Aboriginal at our school" (Morgan 121). Sally and her sister undergo similar humiliating experiences in their schools when they were considered as 'bad influence' on white children.

The Stolen Generation members were hardly given any education. If at all they received any education it was the education for the girls of how to be domestics in a white household, and for boys how to be station workers. In Arthur's words, "Now, if I had been born a white man, my life would have been different. I'd have had an education the proper way, without the whipping" (Morgan 
267). This was what happened in foster institutions in the past. In the novel, Nan emotionally puts it saying, "I can't help it if can't read or write", when Arthur makes fun of her lack of education (Morgan 207).

The amount of hard labour that the children endured in the foster homes and institutions and the mental trauma that resulted from it, can be expressed from the lines of James Miller in his poem, "Six o'Clock...Outa bed", as quoted in "Bringing Them Home":

Six o'clock, out of bed, wash, dress, work, breakfast, work, inferior schooling, home, change clothes, work, wash, tea, bed, nightmares, worry, little sleep, cry. (Bringing 48)

Children in foster care underwent poor living conditions, where they were denied basic needs like food, clothing and shelter. Children were poorly fed and that led to malnutrition and starving. "children living crowded into dormitories, locked in at night with only a bucket for sanitation, permanently hungry, separated from their parents, badly taught by poorly trained teachers, educated sufficiently only to work as domestic servants and farm hands, forbidden to speak their own language" (Brady 3), sums up Veronica Brady in her article "Reading Aboriginal Writing".

Children were also succumbed to physical torture, inhuman punishments and sexual abuse, because of the racial difference. In his testimony, Arthur recollects various instances of the physical torments that he underwent in the mission he was put in. Gladys and Daisy were of no exceptions and they were often subject to harsh and cruel punishments, including physical, verbal and sexual abuse. Sexual abuse was another crucial experience that both boys and girls underwent in the days of foster care which proves that there was no 'protection' of any sort given to them.

The children were not even allowed to ventilate their emotions in any manner. 'crying' over anything was strictly prohibited and if the children disclosed their cry, brutal punishments were given and they were silenced. Gladys recalls her days in Parkerville where the inmates would "turn their faces into the pillow and cry, because they knew if Miss Moore heard them, she'd give them a smack" (Morgan 335) and she reasons out saying, "You didn't cry in front of anyone at the Home, it wasn't done" (Morgan 313). As they were restricted from exhibiting their mental agony, the children chose to give vent to their emotions when they were in the bush, amidst nature. Gladys had a 'crying tree in the bush' as her soul companion to cry with.

However their silence had "two dimensions, that is the conditioned silence and the powerful silence" (Rani
76) and Arthur followed the latter silence as a form of protest against humiliation. While sharing his experience in the mission when he was physically punished by a white man, he boasts saying "I was the only one that didn't cry out.... He beat me harder and harder, ..., but I wasn't going to give him the satisfaction of making me cry" (Morgan 241).

Such physical tortures and mental trauma that the children underwent gave them the fear of being in prison or a concentration camp, instead of the feeling of being at 'home'. Arthur says, 'the mission wasn't anyone's family. They called us inmates then, all us kids, we were all inmates, just like a prison" (Morgan 232). Unnatural deaths in the foster homes and institutions were also quite normal, an unquestionable reality to the children. Gladys wondered at the sudden disappearance of her friend only to be informed later that she was dead. There were also many cases of mysterious deaths occurring when children were being adopted and Gladys witnesses one such death, where one girl was being adopted only for two years by a rich white family and later the news arrived that she died out of "arsenic poisoning". She also expresses the psychological fear of the children saying, "None of us wanted to be adopted after that" (Morgan 318).

The worst social deprivation of being mixedblood children is that they were "accepted neither by Aboriginals nor by white people, thus becoming doubleoutcasts" (Rani 17). As a result they were made to feel sandwiched between two distinct cultures. A Stolen Generation reports, "You hear whitefellas tell you you're a blackfella. But blackfellas tell you you're a whitefella. So you're caught in a half-caste world" (Bringing 176). Daisy also similarly expresses saying, "There I was, stuck in the middle. Too black for the whites and too white for the blacks" (Morgan 415). Even when they try to reunite with their aboriginal families, "the other rejection came, of course, from their Aboriginal people in the community. They called us 'whitewashed', 'coconuts' and things like that; also 'Johnny-come-latelys' (Bringing 209).

All the above factors resulted in the deep psychological, emotional injury that the children were unable to escape from. The experiences left them psychologically and emotionally crippled for life as it is observed by a stolen person, "It's like a hole in your heart that can never heal" (Bringing 154). Peter Read observes, "The children were emotionally, spiritually, intellectually and psychologically deprived, and scars might never heal" (Read 14). In the words of Nene Gare and Patricia Crawford, the mixed-blood children, "separated from their spirit land, witnesses to the most fearful and humiliating 
practices, nothing left to them but the breath in their bodies. Dead and alive still" (Gare 1).

It is said that on 13 February 2008, the then Prime Minister Kevid Rudd finally issued the long awaited apology from the part of the Australian government to the affected members of the Stolen Generation. But many statistical studies prove that several children of Aboriginal descent still remain under foster care even into 2011.

It is an undeniable reality that the members of the Stolen Generation, leading free lives today, still feel detached from their family, language, cultural and spiritual roots. Their basic Aboriginal identity is questioned. The separation is so much that they are not able to identify themselves with their own Aboriginal kith and kin, even after reunion. The life in missions and foster homes has left a deep impact on their lives causing more mental trauma and spiritual ache that can never be healed.

It is laudable that the Aboriginal writers, many of whom also belong to the Stolen Generation, do not stop with providing representative voices for their community, but also have turned activists in their lives by extending their services to the indigenous community through various means, beyond writing. Sally Morgan herself did not stop with voicing the Aboriginal concerns by simply writing her own family history, but is still making as many Aboriginal voices be heard in many other ways. She has been working with the indigenous people for the past eight years, doing editorial work for oral history projects that get published as community resources. She also encourages lot of people to share their stories and helps in documenting them. Famous Aboriginal writer (also a member of Stolen Generation), Doris Pilkington whose Follow the RabbitProof Fence that later emerged as a prize-winning film 'Rabbit-Proof Fence' by Philip Noyce, is also an Aboriginal activist in real life who does her phenomenal role of reporting the social and cultural history of her people, especially from an Aboriginal woman's perspective.

Many active organizations have sprung up in Australia in the recent years that help mixed-race descendants to trace their Aboriginal roots and family members and to reunite them. Peter Read in his report talks about 'Link-Up' a service organization which began in 1981 and gives a sample story of a woman who was introduced to her nephew, which appeared to be her first contact with her family for 57 years. Other organizations like National Sorry Day Committee (NSDC), Stolen Generations Alliance (SGA), Family Link have been formed to help the Stolen Generation members in the process of reunion and healing. To compensate for the stolen wages and to reimburse payment, organizations like
Stolen Wages Working Groups (SWWGs) and The Wampan Wages have also been set in major cities in Australia. The Australian government is also willing to offer the olive branch to the Aboriginal community, by venturing into necessary compensating measures towards achieving the goal of reconciliation.

The role of the "Bringing Them Home" report throws light on the neglected community of mixed-race descendants as Stolen Generation. The report carries personal narratives of more than five hundred Aboriginal people who have been affected by the child removal policies and who belong to the Stolen Generation because of their mixed-race problem. The report also performed diverse functions in promoting healing services among indigenous communities ranging from undoing the various damages done to the affected community to helping the affected members trace their families and thereby providing a sense of belonging and sense of identity. Oral testimonies and written submissions of many Stolen Generation members found in this report stress the validity of the issue and some of them are therefore reflected in this research paper to throw a better light on the burning issue of mixed-race Aborigines and Stolen Generation members.

Both whites and the native Aborigines, only when they shed their taunting memories of the past and move forward to embrace the other race without prejudice, can they extend and relate with each other. The contemporary white Australians cannot be blamed for the cruelty of their ancestors and nor be claimed guilty. Present Australia is also free from the colonial era and therefore there is much space for each to extend a friendly hand to the other and live in harmony as citizens of Australia. Only if both the races wipe out the rigidly framed ideological attitudes, leave behind their traditional stereotypes and mythical ideas about each other and come forward to reach out to the other, will equality be possible. A slight change in attitude, a small step towards reaching out to each other, can do wonders in the life of this victimized race.

\section{REFERENCES}

[1] Bliss, Carolyn. "The Mythology of Family: Three Texts of Popular Australian Culture." New Literatures Review: Post-colonial Revision of Australian Literature 18 (1989): 65-7.

[2] Brady, Veronica. "Reading Aboriginal Writing." Westerly. 39.2. 1994. 41-53. Web. 28 Dec. 2011.

[3] "Bringing Them Home: Report of the National Inquiry into the Separation of Aboriginal and Torres Strait Islander Children from their Families." Sydney: Human Rights and Equal Opportunity Commission, 1997. 
[4] Gare, Nene and Patricia Crawford. "Sally Morgan's My Place - Two Views." Westerly. 1987. 79-84. Web. 28 Dec. 2011.

[5] Hills, Edward. ““'What Country, Friends, Is This?”: Sally Morgan's My Place Revisited." Journal of Commonwealth Literature 32.2 (1997): 103-12.

[6] Kennedy, Rosanne. "The Narrator as Witness. Testimony, Trauma and Narrative Form in My Place." Meridan. 16.2. 1997. 235-60. Web. 28 Dec. 2011.

[7] Morgan, Sally. My Place. New Delhi: Indialog Publications Pvt. Ltd., 2001.

[8] Pruthi, Harpreet. "Racism in Aboriginal World of Sally Morgan's My Place." Journal of Australian Studies: Multiculturalism in Australian Literature 1 (2004): 67-72.

[9] Rani, Sumeetha. Australian Aboriginal Women's Autobiographies: A Critical Study. New Delhi: Prestige Books, 2007.

[10] Read, Peter. "The Stolen Generations: The Removal of Aboriginal children in New South Wales 1883 to 1969." 1981. Web. 7 Dec. 2011.

[11] Smith, Sidonie. "Re-citing, Re-siting and Re-sighting likeness: Reading the Family Archieve in Drucilla Mojeska's Poppy, Donna Williams' Nobody Nowhere and Sally Morgan's My Place." Modern Fiction Studies 40.3 (1994): 527-35.

[12] Sonoda, Hirokazu. "A Preliminary Study of Sally Morgan's My Place." The Otemon Journal of Australian Studies. 35 (2009): 157-170. Web. 6 Feb. 2012.

[13] Thomas, Sue. "Aboriginal Subjection and Affirmation." Meanjin. 47.4. 1998. 755-61. Web. 28 Dec. 2011.

[14] Wanderburgova, Lucie. "The Depiction of the Stolen Generation in My Place and Follow the Rabbit-Proof Fence." 2008. Web. 9 Jan. 2012. 